\title{
Ellagitannin-rich pomegranate extract inhibits angiogenesis in prostate cancer in vitro and in vivo
}

\author{
MARYAM R. SARTIPPOUR ${ }^{1}$, NAVINDRA P. SEERAM ${ }^{1}$, JIAN YU RAO ${ }^{2}$, AUNE MORO $^{1}$, \\ DIANE M. HARRIS ${ }^{1}$, SUSANNE M. HENNING ${ }^{1}$, AMITA FIROUZI ${ }^{1}$, MATTHEW B. RETTIG $^{3,4,5}$, \\ WILLIAM J. ARONSON ${ }^{4,5}$, ALLAN J. PANTUCK ${ }^{4}$ and DAVID HEBER ${ }^{1}$ \\ ${ }^{1}$ Center for Human Nutrition, ${ }^{2}$ Department of Pathology, ${ }^{3}$ Division of Hematology-Oncology, \\ ${ }^{4}$ Department of Urology, ${ }^{5}$ Greater Los Angeles VA Healthcare System, David Geffen School of Medicine, \\ University of California at Los Angeles, Los Angeles, CA, USA
}

Received July 27, 2007; Accepted September 10, 2007

\begin{abstract}
Angiogenesis is critical to tumor growth and is stimulated by tissue hypoxia due to poor oxygen delivery. In turn, cellular hypoxia leads to angiogenesis via the induction of hypoxia-inducible factor- $1 \alpha$ (HIF-1 $\alpha)$ and vascular endothelial growth factor (VEGF) at a cellular level. Pomegranate juice and extracts, which are rich sources of ellagitannins, have been shown to have chemopreventive potential against prostate cancer, but there have been no studies on the effects of an ellagitannin-rich pomegranate extract on angiogenesis. Human prostate cancer cells (LNCaP) and human umbilical vein endothelial cells (HUVEC) were incubated with a pomegranate extract standardized to ellagitannin content (POMx), under normoxic and hypoxic conditions in vitro. Human prostate cancer cells (LAPC4) were injected subcutaneously into severe combined immunodeficient (SCID) mice and the effects of oral administration of POMx on tumor growth, microvessel density, and HIF-1 $\alpha$ and VEGF expression were determined after 4 weeks of treatment. POMx inhibited the proliferation of LNCaP and HUVEC cells significantly under both normoxic and hypoxic conditions. HIF- $1 \alpha$ and VEGF protein levels were also reduced by POMx under hypoxic conditions. POMx decreased prostate cancer xenograft size, tumor vessel density, VEGF peptide levels and HIF-1 $\alpha$ expression after 4 weeks of treatment in SCID mice. These results demonstrate that an ellagitannin-rich pomegranate extract can inhibit tumor-associated angiogenesis as one of several potential mechanisms for slowing the growth of prostate cancer in chemopreventive applications. Further studies in humans are needed to confirm that angiogenesis can be inhibited by an ellagitannin-rich pomegranate extract administered orally as a dietary supplement.
\end{abstract}

Correspondence to: Dr David Heber, UCLA Center for Human Nutrition, Box 951742, Los Angeles, CA 90095-1742, USA

E-mail: dheber@mednet.ucla.edu

Key words: hypoxia inducible factor-1 $1 \alpha$, pomegranate, angiogenesis, vascular endothelial growth factor, prostate cancer

\section{Introduction}

Since the 1990s, evidence has continued to accumulate demonstrating that hypoxia, the insufficient supply of oxygen to tissues to maintain basic biologic function, is a common consequence of the rapid growth of many solid tumors (1-4). Hypoxia is a major driving force of tumor progression in more than $70 \%$ of human cancers including prostate cancer (PCa). Hypoxia mediates this growth-promoting effect in large part through the process of angiogenesis, which is essential to tumor growth beyond 200 microns in diameter (1-4). However, unlike normal tissue vasculature, tumor microvessels formed through angiogenesis are highly disorganized resulting in further hypoxia and subsequent activation of hypoxia-associated cellular transcription factors, which in turn ultimately lead to progression through stages of more aggressive and lethal tumor phenotypes (5).

Hypoxia-inducible factor $1-\alpha(\mathrm{HIF}-1 \alpha)$ induces the expression of genes involved in angiogenesis under hypoxic conditions, is an important regulator of the expression of a number of genes and can affect gene products at both posttranscriptional and post-translational levels (6-8). HIF- $1 \alpha$ and HIF-1ß occur as a heterodimeric protein complex called HIF-1. While HIF-1ß is constitutively expressed, HIF- $1 \alpha$ expression is stimulated by hypoxia $(6,9)$. Under normoxic conditions, HIF- $1 \alpha$ is rapidly degraded $(10,11)$, but hypoxia induces a rapid increase in HIF-1 $\alpha$ protein stability and transcriptional activity $(12,13)$. The growth of PCa is dependent on blood supply and the induction of new blood vessels through angiogenesis (14). Tumor-induced angiogenesis is regulated by cell-produced factors such as vascular endothelial growth factor (VEGF) and VEGF levels are elevated in prostate cancer in both animal models and human PCa (1). Tumor hypoxia is considered the most potent stimulus for VEGF and its expression is transcriptionally regulated by hypoxiainducible factor-1 (HIF-1) $(1,15,16)$. Moreover, androgens, which play a prominent role in $\mathrm{PCa}$ etiology and progression, have been shown to activate HIF-1 $\alpha$ and VEGF expression in human prostate cancer ( $\mathrm{LNCaP}$ ) cells (17).

The pomegranate fruit peel and juice, derived from pressed whole fruits, contain high levels of polyphenols known as 
ellagitannins. Pomegranate ellagitannins have been shown to inhibit PCa cell proliferation in vitro and human PCa xenograft growth in vivo (18-20). The most abundant ellagitannin in pomegranate juice is called punicalagin. The pomegranate extract used in our investigations contained $37 \%$ punicalagin and $3.5 \%$ ellagic acid. Ellagitannins are hydrolyzed in the intestine to release ellagic acid, which is absorbed into blood circulation within $1 \mathrm{~h}$ after the ingestion of pomegranate juice (21). In order to determine whether pomegranate ellagitannins inhibit angiogenesis, human umbilical vein endothelial cells (HUVEC) were exposed to the standardized pomegranate ellagitannin extract (POMx) under normoxic and hypoxic conditions. In addition, to determine whether pomegranate administration can inhibit prostate tumor growth via inhibition of angiogenesis in vitro and in vivo, androgen-dependent $\mathrm{PCa}$ cells (LNCaP, LAPC4) were treated with POMx in cell culture (LNCaP) or as xenografts (LAPC4) in severe combined immunodeficient (SCID) mice or in vehicle-treated control animals.

\section{Materials and methods}

Pomegranate extract (POMx). POMx powder was derived from the skin and arils of pomegranate fruit (Punica granatum L., Wonderful variety, Paramount Farms, Lost Hills, CA) without seeds and standardized to $37 \%$ ellagitannins (as punicalagins) and $3.5 \%$ free ellagic acid as reported (22). POMx was administered dissolved in phosphate-buffered saline (PBS) to cell culture in concentrations from 0-10 $\mu \mathrm{g} / \mathrm{ml}$. Mice received $0.8 \mathrm{mg}$ POMx per day dissolved in $50 \mu 1 \mathrm{PBS}$ (0.3 mg punicalagin). Based on the punicalagin content and calculated per body weight, this dose is equivalent to the human consumption of ten 8 -oz cups of single-strength pomegranate juice commercially available for consumption. However, considering the difference in metabolic rate and caloric intake between mice and humans, the direct comparison of mouse and human dose based on body weight is not recommended. As evaluated by Schneider et al (23), interspecies extrapolation should be based on caloric intake. Therefore the conversion based on caloric intake from mouse to human revealed that the mouse dose is equivalent to the human consumption of 1.7 cups of pomegranate juice.

Hypoxic conditions. Hypoxic conditions were maintained by incubation of cells in an anaerobic chamber. The oxygen tension was kept at $1 \%$ using a compact oxygen controller (ProOx Model 110, BioSpherix, Redfield, NY) with a residual gas mixture composed of $95 \% \mathrm{~N}_{2}$, and $5 \% \mathrm{CO}_{2}$.

Cell culture. Human LNCaP cells were purchased from American Tissue Type Culture Collection (Rockville, MD). Cells were maintained in RPMI medium 1640 with $10 \%$ heat-inactivated FBS (fetal bovine serum), 100 units $/ \mathrm{ml}$ penicillin, and $100 \mu \mathrm{g} / \mathrm{ml}$ streptomycin. Human umbilical vein endothelial cells (HUVEC) were purchased from Cascade Biologics (Portland, OR). The cells were plated on tissue culture flasks coated with $1.5 \%$ gelatin (Difco, Detroit, MI) in phosphate-buffered saline (PBS). They were maintained in endothelial growth media (EGM) completed with basic fibroblast growth factor (bFGF), heparin, fetal calf serum
(FCS), penicillin, streptomycin and amphotericin-B. Cells were incubated at $37^{\circ} \mathrm{C}$ in a humidified atmosphere of $5 \% \mathrm{CO}_{2}$.

In vitro assay of proliferation. Cells were plated onto 48-well culture plates at 10,000 cells/well for both LNCaP and HUVEC cells and incubated at $37^{\circ} \mathrm{C}$ in $5 \% \mathrm{CO}_{2}$ for $3 \mathrm{~h}$ in appropriate media as detailed above. Cells were exposed to POMx dissolved in PBS under aerobic or anaerobic conditions for $6 \mathrm{~h}$. One $\mu \mathrm{Ci}$ of [methyl- $\left.{ }^{3} \mathrm{H}\right]$-thymidine (Amersham, Piscataway, $\mathrm{NJ}$ ) was added to each well under the above conditions. After another 12-15 h, the cells were washed with PBS, fixed with trichloroacetic acid, washed with ethyl alcohol, and lysed with sodium hydroxide, using methods described previously (24). After addition of glacial acetic acid, cell lysate radioactivity was measured using a scintillation counter (Beckman Coulter, Fullerton, CA). In vitro assays were performed in triplicate.

Quantification of VEGF peptide levels. VEGF secreted into cell medium and serum VEGF concentrations from animals bearing xenografts were determined using previously described methods $(25,26)$. The cell culture media over $48 \mathrm{~h}$ of treatment were collected, centrifuged at $250 \mathrm{x}$ g to remove debris, and frozen until further analysis. VEGF concentrations were determined using a quantitative enzyme-linked immunosorbent assay (ELISA, R\&D Systems, Minneapolis, MN). The amount of VEGF immunoreactivity was calculated using recombinant human VEGF standards present on each microtiter plate. Optical densities were determined at $450 \mathrm{~nm}$ using a microtiter plate spectrophotometer (Molecular Devices, Sunnyvale, CA).

Western analysis. Cell lysates from LNCaP and HUVEC cells were centrifuged at $12,000 \mathrm{x}$ g for $10 \mathrm{~min}$, and the supernatant retained. The protein content of cell lysate was estimated according to the Bradford method using a colorimetric assay (Bio-Rad, CA). Approximately $50 \mu \mathrm{g}$ of protein (27) was separated by a 7.5\% SDS-PAGE, and transferred to a nitrocellulose membrane by electrophoretic blotting. The membrane was blocked for $1 \mathrm{~h}$ with $5 \%$ non-fat dry milk in Tris-buffered saline (TBS), and then incubated for $1 \mathrm{~h}$ with a 1:500 dilution of anti-human HIF- $1 \alpha$ of human origin (Santa Cruz Biotechnology, Santa Cruz, CA). The blots were then washed three times over $1 \mathrm{~h}$ in TBST (TBS with $0.1 \%$ Tween-20), incubated for $1 \mathrm{~h}$ with horseradish peroxidaseconjugated secondary antibody goat anti-rabbit $\operatorname{IgG}(1: 2,000)$, and then washed in TBST as before. The membranes were developed using the Supersignal West Pico chemiluminescent Western blotting detection system (Pierce, Arlington Heights, IL).

Animal studies. All procedures carried out in mice were approved by the UCLA Animal Research Committee. Male SCID mice (Taconic Farm, Germantown, NY) were bred in a pathogen-free colony (27), where they were housed in groups of four per cage and fed sterilized food pellets and water. Androgen-dependent LAPC4 prostate cancer cells $\left(2 \times 10^{5}\right.$ LAPC4 cells per animal; gift from Charles Sawyers) were implanted subcutaneously into the shoulders of twenty-four 5-week-old SCID mice (Taconic Farm). Two weeks after tumor cell injection, POMx $(0.8 \mathrm{mg} / 50 \mu \mathrm{l} \mathrm{PBS})$ or vehicle 
control (50 $\mu$ 1 PBS) was administered for four weeks ( $\mathrm{n}=12$ per group) orally 5 days per week (Monday-Friday). Oral dosing was accomplished by gently securing the mouse with one hand and delivering the POMx or vehicle control via an animal feeding needle (Biomedical Needles, Popper and Sons Inc., New Hyde Park, NY) attached to a 1-ml tuberculin syringe. Tumor size was measured with calipers three times a week starting at day 7 . After 4 weeks, mice were sacrificed to obtain both serum samples and tumor tissues.

Immunohistochemistry. Immunohistochemistry was performed as previously described (27). Paraffin-embedded tumor specimens cut into $5-\mu \mathrm{m}$ sections were baked at $65^{\circ} \mathrm{C}$ for 30 min. Hematoxylin and eosin (H\&E) staining was used to identify areas of necrotic tumor. Paraffin was removed with xylene, followed by elution with graded alcohols. Antigen retrieval was carried out with $0.01 \mathrm{~mol} / 1$ sodium citrate, $\mathrm{pH} 6.0$ in a $95^{\circ} \mathrm{C}$ water bath for $20 \mathrm{~min}$, and $1 \mathrm{mg} / \mathrm{ml}$ trypsin (SigmaAldrich, St. Louis, MO) at room temperature for $3 \mathrm{~min}$. Immunostaining was performed with a peroxidase rabbit readyto-use system (Dako Envision). The slides were incubated at room temperature in Dako antigen block reagent to block non-specific antibody binding, and then with the rabbit antivon Willebrand factor (vWf, Dako, Carpinteria, CA) primary antibody at 1:250 dilution for $1 \mathrm{~h}$ or monoclonal anti-HIF- $1 \alpha$ at 1:250 dilution (Sigma-Aldrich) at $37^{\circ} \mathrm{C}$ for $2 \mathrm{~h}$. Then sections were incubated with Dako second antibody to rabbit for $30 \mathrm{~min}$, and developed with Dako DAB (diaminobenzidine) solution. Tissues were stained with Gill's hematoxylin, dehydrated with graded alcohols, and mounted. Positively stained vessels were counted in five separate fields for each specimen using an Olympus model BH2 microscope. Following the method established by Weidner et al (28), fields containing the highest density of vWf-positive vessels, i.e. 'bursts', were identified at scanning power and then counted at x 200 or x400 magnification. The numbers for the five fields were averaged. For HIF- $1 \alpha, \%$ of cell staining and staining intensity (from 0 to $3^{+}$) were determined.

Statistical methods. For the cell proliferation assays, data were expressed as a percentage of untreated cells (i.e. treatment value-blank/vehicle value-blank), with mean \pm SE for at least three separate experiments. Data were analyzed by either student's t-test or one-way ANOVA followed by Dunnett's multiple range test $(\alpha=0.05)$ with Graph Pad Prism 3.0 (Graph Pad Software Inc., San Diego, CA) as appropriate.

\section{Results}

In vitro studies. $\mathrm{POMx}$ inhibited the proliferation of endothelial cells (HUVEC), a measure of angiogenic potential in vitro, under both normoxic and hypoxic conditions (Fig. 1). The $\mathrm{IC}_{50}$ for the inhibition of proliferation under normoxic and hypoxic conditions was $6.7 \pm 0.5 \mu \mathrm{g} / \mathrm{ml}$ under normoxic conditions and $2.2 \pm 0.2 \mu \mathrm{g} / \mathrm{ml}$ under hypoxic conditions. In addition, POMx inhibited the proliferation of androgendependent human cancer cells (LNCAP) under hypoxic conditions (Fig. 1). The $\mathrm{IC}_{50}$ for inhibition of proliferation for LNCaP cells was $2.0 \pm 0.2 \mu \mathrm{g} / \mathrm{ml}$ under hypoxic conditions and $5.7 \pm 0.5 \mu \mathrm{g} / \mathrm{ml}$ under normoxic conditions. Therefore,
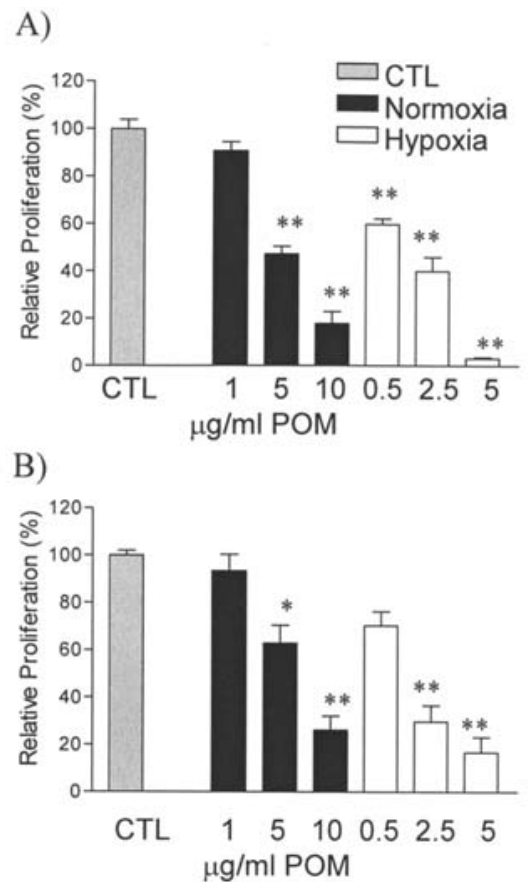

Figure 1. Effect of POMx on cell proliferation. (A) Human prostate cancer cells (LNCaP) and (B) HUVEC were cultured in the presence or absence of $\mathrm{POMx}$ under normoxic and hypoxic conditions. Data represent the mean $\pm \mathrm{SE}$ of three different experiments. ${ }^{*} \mathrm{p}<0.05$, and ${ }^{* *} \mathrm{p}<0.001$ compared to untreated control (CTL)

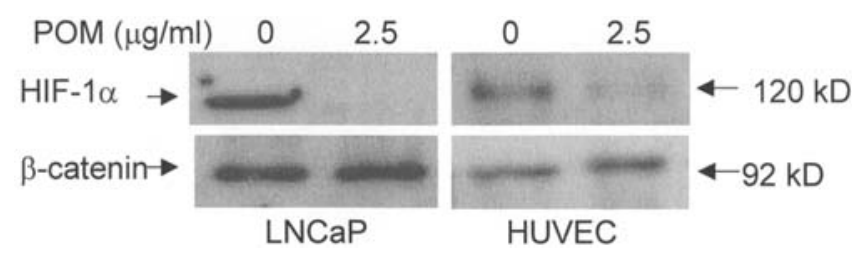

Figure 2. Effect of POMx on HIF-1 $\alpha$ protein level. (A) Human prostate cancer cells (LNCaP) and (B) HUVEC were cultured in serum-free media in the absence or presence of POMx for $4 \mathrm{~h}$ under hypoxic conditions. Cells were lysed and Western blot analysis was carried out as detailed in Materials and methods.

both prostate cancer cells and HUVEC were more sensitive to inhibition by POMx under hypoxic conditions (Fig. 1A and B).

Furthermore, this growth inhibition under hypoxic conditions was associated with a reduction in HIF-1 $\alpha$ protein concentrations (Fig. 2). Hypoxic exposure of both LNCaP and HUVEC to $2.5 \mu \mathrm{g} / \mathrm{ml}$ of POMx for $48 \mathrm{~h}$ reduced HIF- $1 \alpha$ protein levels. As expected, there was no effect of POMx exposure on HIF-1 $\alpha$ under normoxic conditions (data not shown). Moreover, under hypoxic conditions, the incubation of LNCaP cells and HUVEC with $0-5 \mu \mathrm{g} / \mathrm{ml} \mathrm{POMx}$ for $48 \mathrm{~h}$ decreased the VEGF secreted in the condition media in a dose-dependent manner (Fig. 3A and B). Under normoxic conditions no effect of POMx administration on VEGF secretion was observed (data not shown).

In vivo mouse studies. Tumor volume in SCID mice bearing LAPC4 xenografts implanted 2 weeks prior to POMx treatment was greatly decreased after POMx treatment compared to 
A)

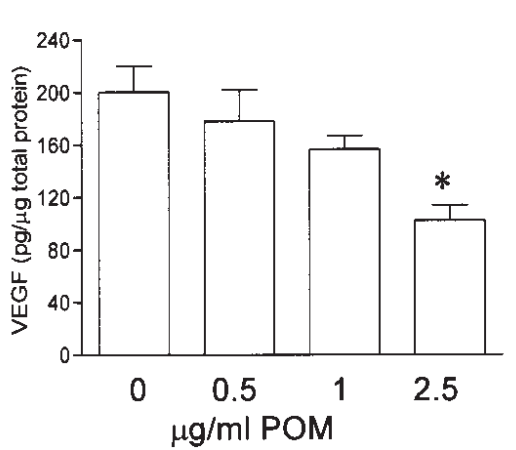

B)

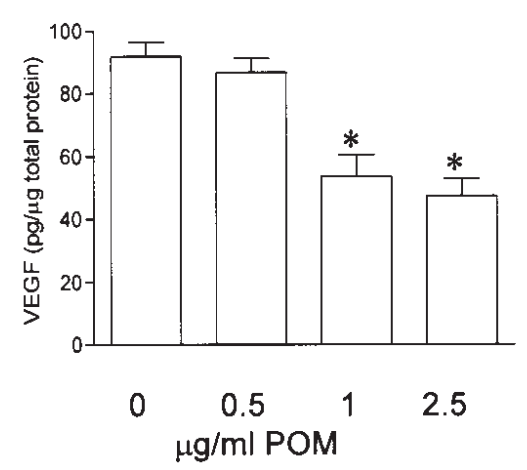

Figure 3. Effect of POMx on VEGF levels secreted into conditioned media. (A) Human prostate cancer cells LNCaP and (B) HUVEC were cultured in serum-free media in the absence or presence of POMx for $48 \mathrm{~h}$ under hypoxic conditions. Supernatant VEGF concentrations were determined, as detailed in Materials and methods. ${ }^{*} \mathrm{p}<0.001$ compared to untreated control.

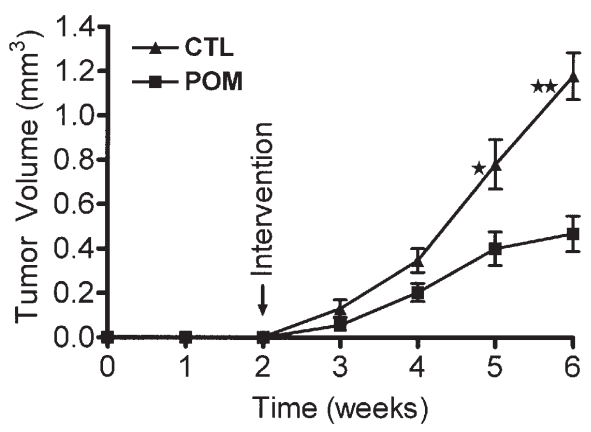

Figure 4. Effect of POMx on prostate cancer xenografts. SCID mice were injected $2 \times 10^{5}$ LAPC4 cells subcutaneously. Control mice were fed PBS, and experimental mice were fed POMx at $0.8 \mathrm{mg}$ dissolved in $0.05 \mathrm{ml}$ PBS for five days per week. The tumor size was measured in three dimensions with calipers three times a week and expressed as volume. Data represent the mean $\pm \mathrm{SE}$ of one experiment ( $\mathrm{n}=12$ per group). ${ }^{*} \mathrm{p}<0.01$ and ${ }^{*} \mathrm{p}<0.001$, compared to control (CTL).

vehicle treatment. Mean tumor volume in POMx-treated mice was $199.3 \pm 37.2 \mathrm{~mm}^{3}$ compared to $1179.7 \pm 105.9 \mathrm{~mm}^{3}$ in control animals at day 28 (Fig. 4). The VEGF peptide concentration in mouse serum was significantly higher in the control group $(15.7 \pm 5.3 \mathrm{pg} / \mathrm{ml})$ compared to the POMx-treated group $(3.8 \pm 1.4 \mathrm{pg} / \mathrm{ml})$.

Tumors analyzed by immunohistochemistry to determine the extent of angiogenesis and reviewed by a Board-certified pathologist (J.Y.R) demonstrated that POMx treatment
A)

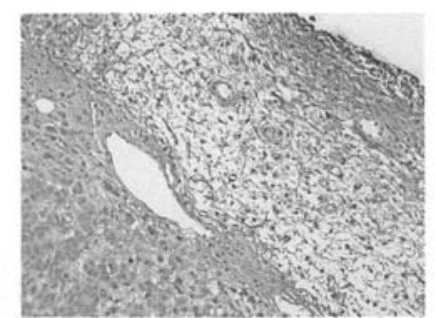

CTL

Overall

vessel density: $35.2 \pm 3.2$

B)

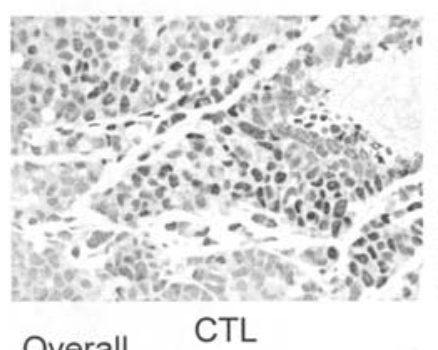

Overall

HIF- $1 \alpha$ level: $35.8 \pm 3.0$

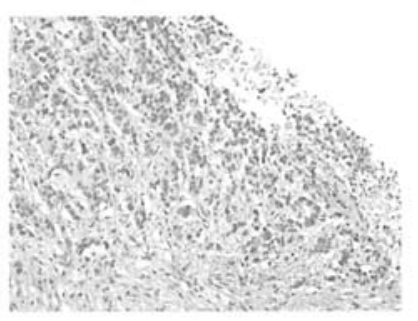

POM

$15.9 \pm 2.1$ *
Figure 5. (A) Effect of POMx on the tumor blood vessels. Mouse tumor specimens were stained with vWf (von Willebrand factor) antibody and vessel density was presented per high power field. ${ }^{*} \mathrm{p}<0.05$ compared to untreated control (CTL). (B) HIF-1 $\alpha$ level in LAPC4 prostate cancer xenografts. Tumor specimens were stained with HIF- $1 \alpha$ antibody and HIF- $1 \alpha$ levels were presented per high power field. ${ }^{*} \mathrm{p}<0.05$ compared to untreated CTL.

significantly decreased the overall blood vessel density in mouse tumors treated with the POMx $(15.9 \pm 2.1$ vessels/high power field) compared to the animals given vehicle alone [35.2 \pm 3.2 vessels/high power field (hpf), p<0.05] (Fig. 5A). In addition, positively stained HIF- $1 \alpha$ in tumor xenograft tissue was significantly decreased in the POMx-treated group $(23.3 \pm 1.8$ cells/hpf, $\mathrm{p}<0.05)$ by comparison to vehicle-treated animals $(35.8 \pm 3.0$ cells/hpf) (Fig. 5B).

\section{Discussion}

This is the first demonstration that pomegranate ellagitannins inhibit angiogenesis in $\mathrm{PCa}$. Our group has previously published the preliminary observation in 48 men with recurrent $\mathrm{PCa}$ that daily pomegranate juice consumption can extend prostate specific antigen (PSA) doubling time from 15 to 54 months (29). This important clinical index of PCa progression was reduced in $83 \%$ of pomegranate juice consuming patients. These findings are currently being confirmed in a larger multicenter, randomized, placebo-controlled clinical trial. In the present study, using human prostate cell xenografts (LAPC4), in SCID mice, we have demonstrated the inhibition of both tumor growth and angiogenesis. While this observation might be interpreted as secondary only to inhibition of tumor growth with secondary inhibition of angiogenesis, our in vitro observations that pomegranate ellagitannins inhibited HIF-1 $\alpha$ expression and VEGF secretion clearly suggest that pomegranate ellagitannins have a direct effect on angiogenesis. The failure to see inhibition under normoxic conditions 
demonstrates that the effects are specific to hypoxic conditions relevant to in vivo tumor angiogenesis.

The pomegranate ellagitannin enriched extract (POMx) tested in vitro and in vivo in the current study has been carefully characterized by our group (22). Pomegranate (Punica granatum L.) fruits are widely consumed fresh and as squeezed juice. During commercial juice processing, ellagitannins abundant in the fruit peel, are extracted in large quantities into the juice. These polyphenols account for $92 \%$ of the total antioxidant activity in the juice (30). However the most predominant ellagitannin found in pomegranate juice is punicalagin (2,3-hexahydroxydiphenoyl-4,6-gallagylglucose), a large polyphenol with a molecular weight of over $1000 \mathrm{Da}$. It is not absorbed intact in humans or mice, but is hydrolyzed to ellagic acid by the intestinal flora. Ellagic acid in turn is absorbed and conjugated in the liver and finally excreted in the urine (21).

The dose used in the present study is equivalent to 1.7 cups ( $8 \mathrm{oz}$ ) of pomegranate juice per person per day when calculated using caloric demand scaling as an interspecies extrapolation method (23). The validity of this method of interspecies extrapolation was confirmed by the observation that plasma ellagic acid concentrations were very similar in humans and mice after administration of either $0.8 \mathrm{mg}$ of POMx to mice (plasma, $0.045 \mu \mathrm{mol} / \mathrm{l}$ ) (31) compared to $180 \mathrm{ml}$ of liquid pomegranate extract equivalent to 1.5 cups $(8 \mathrm{oz})$ of pomegranate juice in humans (plasma, $0.06 \mu \mathrm{mol} / \mathrm{l}$ ) (21). The similarity of the plasma concentrations of ellagic acid between human and mouse supports the fact that the conversion of dose based on caloric intake should be utilized.

In vitro studies are often criticized because they frequently study polyphenols in levels that are not physiologically achievable and fail to consider relevant metabolism of bioactive substances. For these reasons, we extended our mechanistic in vitro studies to an in vivo xenograft model. While we were able to demonstrate that the anti-angiogenic effect of POMx may be due to suppression of HIF-1 $\alpha$ protein levels, we cannot entirely exclude the possibility that pomegranate ellagitannins affect multiple targets simultaneously. For example, other upstream signaling pathways, such as PI3K-Akt and mammalian target of rapamycin (mTOR), could be involved as the primary target (32). In addition, angiogenesis has been demonstrated to be regulated in cancer cells by multiple cytokines, growth factors and MMPs (33). Further studies are needed to determine the primary target of pomegranate ellagitannins and its metabolites.

Angiogenesis is part of the inflammatory response and inflammation is universally found in prostate tissues obtained at prostatectomy (34). There is also evidence that nuclear localization of nuclear factor $\kappa \mathrm{B}(\mathrm{NF}-\kappa \mathrm{B})$ in prostate tissues is a predictor of PCa recurrence (35). Pomegranate polyphenols were shown to inhibit NF-кB in skin cancer cells (36), and our group has subsequently demonstrated this in prostate cancer cells and xenografts (unpublished data). It is possible that the anti-inflammatory effects of pomegranate ellagitannins will have additional effects on tumor angiogenesis. This possibility is currently under study in our laboratory.

Adenocarcinoma of the prostate is currently the most common malignancy in men in the United States comprising $29 \%$ of all cancers. There has been a trend toward improved survival in PCa over the past several years. PCa 5-year survival rates have increased from $67 \%$ for the period of 1974-1976 to $92 \%$ for the period of 1989-1995 (37). However, PCa remains the second most common cause of cancer death in men in the United States, accounting for $11 \%$ of all cancer deaths. Natural dietary agents have received increasing investigative attention as non-toxic approaches to the chemoprevention and active management of PCa. There are limited treatment options for patients who have undergone primary therapy with curative intent and who have progressive elevation of their PSA without documented evidence of metastatic disease. Given our recent observations of effects of pomegranate juice in PCa patients (29), the current study contributes to the increasing body of evidence demonstrating the chemopreventive potential of pomegranate ellagitannins. These findings strongly suggest the potential of pomegranate ellagitannins for prevention of the multifocal development of PCa as well as to prolong survival in the growing population of PCa survivors of primary therapy. Therefore clinical trials with well-characterized and standardized pomegranate ellagitannin extracts, as primary or adjuvant therapy, in men with PCa are warranted.

\section{Acknowledgements}

Grant support was received from UCLA Clinical Nutrition Research Unit (NIH Grant CA 42710), NIH Nutrition and Obesity Training Grant (T32 DK07688), UCLA Prostate SPORE Grant P50 CA 92131, Veterans Administration, Greater Los Angeles Healthcare System and the Lynda and Stewart Resnick Revocable Trust.

\section{References}

1. Forsythe JA, Jiang BH, Lyer NV, et al: Activation of vascular endothelial growth factor gene transcription by hypoxia-inducible growth factor 1. Mol Cell Biol 6: 4604-4613, 1996.

2. Harris AL: Hypoxia - A key regulatory factor in tumor growth. Nat Rev Cancer 2: 38-47, 2002.

3. Belozerov VE and Van Meir EG: Hypoxia inducible factor-1 $\alpha$ : a novel target for cancer therapy. Anti-Cancer Drugs 16: 901-909, 2005.

4. Zhong H, De Marzo AM, Laughner E, et al: Overexpression of hypoxia-inducible factor 1alpha in common human cancers and their metastases. Cancer Res 59: 5830-5835, 1999.

5. Shannon AM, Bouchier-Hayes DJ, Condron CM and Toomey D: Tumor hypoxia, chemotherapeutic resistance and hypoxia-related therapies. Cancer Treat Rev 29: 297-307, 2003.

6. Wang GL and Semenza GL: Purification and characterization of hypoxia-inducible factor 1. J Biol Chem 270: 230-1237, 1995.

7. Maxwell PH, Dachs GU, Gleadle JM, et al: Hypoxia-inducible factor-1 modulates gene expression in solid tumors and influences both angiogenesis and tumor growth. Proc Natl Acad Sci USA 94: 8104-8109, 1997.

8. Huang LE, Arany Z, Livingston DM and Bunn HF: Activation of hypoxia-inducible transcription factor depends primarily upon redox-sensitive stabilization of its alpha subunit. J Biol Chem 271: 32253-32259, 1996.

9. Wang GL, Jiang BH, Rue EA and Semenza GL: Hypoxiainducible factor 1 is a basic-helix-loop-helix-PAS heterodimer regulated by cellular $\mathrm{O}_{2}$ tension. Proc Natl Acad Sci USA 92: 5510-5514, 1995.

10. Salceda S and Caro J: Hypoxia-inducible factor 1 alpha (HIF-1alpha) protein is rapidly degraded by the ubiquitinproteasome system under normoxic conditions. Its stabilization by hypoxia depends on redox-induced changes. J Biol Chem 272: 22642-22647, 1997.

11. Kallio PJ, Wilson WJ, O'Brien S, et al: Regulation of the hypoxia-inducible transcription factor 1alpha by the ubiquitinproteasome pathway. J Biol Chem 274: 6519-6525, 1999. 
12. Ivan M, Kondo K, Yang H, et al: HIFalpha targeted for VHLmediated destruction by proline hydroxylation: implications for $\mathrm{O}_{2}$ sensing. Science 292: 464-468, 2001.

13. Jaakkola P, Mole DR, Tian YM, et al: Targeting of HIF-alpha to the von Hippel-Lindau ubiquitylation complex by $\mathrm{O}_{2}$-regulated prolyl hydroxylation. Science 292: 468-472, 2001.

14. Zhong H, Semenza GL, Simons JW and De Marzo AM: Upregulation of hypoxia-inducible factor 1alpha is an early event in prostate carcinogenesis. Cancer Detect Prev 28: 88-93, 2004.

15. Carmeliet P, Dor Y, Herbert JM, et al: Role of HIF-1alpha in hypoxia-mediated apoptosis, cell proliferation and tumour angiogenesis. Nature 394: 485-490, 1998.

16. Ryan HE, Lo J and Johnson RS: HIF- 1 alpha is required for solid tumor formation and embryonic vascularization. EMBO J 17: 3005-3015, 1998.

17. Mabjeesh NJ, Willard MT, Frederickson CE, et al: Androgens stimulate hypoxia-inducible factor 1 activation via autocrine loop of tyrosine kinase receptor/phosphatidylinositol 3'-kinase/ protein kinase B in prostate cancer cells. Clin Cancer Res 9: 2416-2425, 2003

18. Afaq F, Saleem M, Krueger CG, Reed JD and Mukhtar H: Anthocyanin- and hydrolyzable tannin-rich pomegranate fruit extract modulates MAPK and NF-кB pathways and inhibits skin tumorigenesis in CD-1 mice. Int J Cancer 113: 423-433, 2005.

19. Lansky EP, Jiang W, Mo H, et al: Possible synergistic prostate cancer suppression by anatomically discrete pomegranate fractions. Invest New Drugs 23: 11-20, 2005.

20. Albrecht M, Jiang W, Kumi-Diaka J, et al: Pomegranate extracts potently suppress proliferation, xenograft growth, and invasion of human prostate cancer cells. J Med Food 7: 274-283, 2004.

21. Seeram NP, Henning SM, Zhang Y, et al: Pomegranate juice ellagitannin metabolites are present in human plasma and some persist in urine for up to 48 hours. J Nutr 136: 2481-2485, 2006.

22. Seeram NP, Lee R, Hardy ML and Heber D: Rapid large-scale purification of ellagitannins from pomegranate husk, a by-product of the commercial juice industry. Sep Purific Tech 41: 49-55, 2005.

23. Schneider K, Oltmanns J and Hassauer M: Allometric principles for interspecies extrapolation in toxicological risk assessment empirical investigations. Regul Toxicol Pharmacol 39: 334-347, 2004.

24. Sartippour M, Heber D, Lu Q, et al: Green tea and its catechins inhibit breast cancer xenografts. Nutr Cancer 40: 149-156, 2001.
25. Sartippour MR, Seeram N, Heber D, et al: Rabdosia rubescens inhibits breast cancer growth and angiogenesis. Int J Oncol 26: 121-127, 2005.

26. Sartippour MR, Shao ZM, Heber D, et al: Green tea inhibits vascular endothelial growth factor (VEGF) induction in human breast cancer cells. J Nutr 132: 2307-2311, 2002.

27. Sartippour MR, Pietras R, Marquez-Garban DC, et al: The combination of green tea and tamoxifen is effective against breast cancer. Carcinogenesis 27: 2424-2433, 2006.

28. Weidner N, Semple JP, Welch WR and Folkman J: Tumor angiogenesis and metastasis: correlation in invasive breast carcinoma. N Engl J Med 324: 1-8, 1991.

29. Pantuck AJ, Leppert JT, Zomorodian N, et al: Phase II study of pomegranate juice for men with rising prostate-specific antigen following surgery or radiation for prostate cancer. Clin Cancer Res 2: 4018-4026, 2006.

30. Gil MI, Tomas-Barberan FA, Hess-Pierce B, et al: Antioxidant activity of pomegranate juice and its relationship with phenolic composition and processing. J Agric Food Chem 48: 4581-4589, 2000 .

31. Seeram NP, Aronson WJ, Zhang Y, et al: Pomegranate ellagitannin derived metabolites inhibit prostate cancer growth and localize to the mouse prostate gland. J Agric Food Chem 55: 7777-7785, 2007.

32. Sun HL, Liu YN, Huan YT et al: YC-1 inhibits HIF-1 expression in prostate cancer cells: contribution of Akt/NF- $\mathrm{kB}$ signaling to HIF- $1 \alpha$ accumulation during hypoxia. Oncogene 26: 3941-3951, 2006.

33. Lee S, Jilani SM, Nikolova GV, et al: Processing of VEGF-A by matrix metalloproteinases regulates bioavailability and vascular patterning in tumors. J Cell Biol 169: 681-691, 2005.

34. De Marzo AM, Marchi VL, Epstein JI and Nelson WG: Proliferative inflammatory atrophy of the prostate: implications for prostatic carcinogenesis. Am J Pathol 155: 1985-1992, 1999.

35. Domingo-Domenech J, Mellado B, Ferrer B, et al: Activation of nuclear factor-kappaB in human prostate carcinogenesis and association to biochemical relapse. Br J Cancer 93: 1285-1294, 2005.

36. Malik A, Afaq F, Sarfaraz S, et al: Pomegranate fruit juice for chemoprevention and chemotherapy of prostate cancer. Proc Natl Acad Sci USA 102: 14813-14818, 2005.

37. Greenlee RT, Murray T, Bolden S and Wingo PA: Cancer statistics, 2000. CA Cancer J Clin 50: 7-33, 2000. 